\title{
Zorg en ondersteuning aan oudere arbeidsmigranten
}

Vanaf de zestiger jaren van de vorige eeuw kent Nederland verscheidene groeperingen arbeidsmigranten, voornamelijk uit de landen rond de Middellandse Zee. De meeste van hen uit de Noordelijke landen rond de Middellandse Zee (Italië, Spanje, Joegoslavië) keerden in de loop van de jaren terug naar hun land van herkomst, omdat daar de economische en politieke omstandigheden beter geworden waren. Vele migranten uit Marokko en Turkije deden dat niet. In het interview zegt burgemeester van Arnhem Ahmed Marcouch hierover: "Niet zozeer oorlog, maar wel de interne spanningen, het gebrek aan perspectief en militaire regimes maakten dat mensen hunkerden naar een land, een plek waar zij een beter leven konden hebben.” Dat was een belangrijke reden om te komen en ook te blijven, naast gezinshereniging, betere voorzieningen op het gebied van de gezondheidszorg, inkomen en dergelijke. Intussen is de eerste generatie van deze groep migranten gepensioneerd en oud geworden.

In dit nummer willen we nagaan hoe het er momenteel met hen voor staat bij het verkrijgen van hulp en ondersteuning bij het ouder worden. Wat zijn de ontwikkelingen sinds 20-30 jaar geleden toen, naast de mogelijkheid om terug te keren naar het land van herkomst, onder de ouderen de overtuiging leefde dat zij binnen de familiekring en eigen gemeenschap op voldoende hulp en ondersteuning konden rekenen?

David Talloen en Olivia Vanmechelen constateren in hun bijdrage over zorg en on- dersteuning aan oudere arbeidsmigranten dat er weliswaar sprake is van "een verschuiving van gastarbeider naar Belgische ouderen met een migratieachtergrond", maar dat zij nog moeilijk de weg vinden naar professionele zorgvoorzieningen.

Tineke Fokkema \& Nina Conkova schetsen een sociaal-demografisch profiel van Turkse en Marokkaanse ouderen in Nederland en België. Zij stellen vast dat de Turkse en Marokkaanse migrantenbevolking snel aan het vergrijzen is, waarmee ook de totale ouderenpopulatie geleidelijk meer verschillende tinten grijs kent.

Chandra Verstappen en Jennifer van den Broeke geven aan dat steeds meer kinderen de zorg en ondersteuning van hun ouders met een migratieachtergrond willen delen met professionals. Dichtbij, liefst in de eigen wijk. En passend bij de behoefte van hun ouders. Daarvoor zijn cultuursensitiviteit en samenwerking onontbeerlijk.

Tenslotte beschrijft Ibrahim Yerden dat pendelen deel uitmaakt van het "goed ouder worden" van ouderen met een migratieachtergrond en het dilemma van terugkeer (voorgoed) naar het land van herkomst opheft.

Het een en ander is dus in beweging en er is op het vlak van zorg en ondersteuning aan oudere arbeidsmigranten nog voldoende te ontdekken en ontwikkelen.

Franka Bakker \& Toon Verlaan 